\title{
Consequences of sludge composition on combustion performance derived from thermogravimetry analysis
}

\author{
Meiyan Li, Benyi Xiao, Xu Wang, Junxin Liu* \\ Research Center for Eco-Environmental Sciences, Chinese Academy of Sciences, 18 Shuangqing Road, Haidian District, Beijing 100085, PR China
}

\section{A R T I C L E I N F O}

Article history:

Received 17 April 2014

Accepted 2 October 2014

Available online 25 October 2014

\section{Keywords:}

Sewage sludge

Combustion

Sludge composition

Thermogravimetric analysis

\begin{abstract}
A B S T R A C T
Wastewater treatment plants produce millions of tons of sewage sludge. Sewage sludge is recognized as a promising feedstock for power generation via combustion and can be used for energy crisis adaption. We aimed to investigate the quantitative effects of various sludge characteristics on the overall sludge combustion process performance. Different types of sewage sludge were derived from numerous wastewater treatment plants in Beijing for further thermogravimetric analysis. Thermogravimetric-differential thermogravimetric curves were used to compare the performance of the studied samples. Proximate analytical data, organic compositions, elementary composition, and calorific value of the samples were determined. The relationship between combustion performance and sludge composition was also investigated. Results showed that the performance of sludge combustion was significantly affected by the concentration of protein, which is the main component of volatiles. Carbohydrates and lipids were not correlated with combustion performance, unlike protein. Overall, combustion performance varied with different sludge organic composition. The combustion rate of carbohydrates was higher than those of protein and lipid, and carbohydrate weight loss mainly occurred during the second stage $\left(175-300^{\circ} \mathrm{C}\right)$. Carbohydrates have a substantial effect on the rate of system combustion during the second stage considering the specific combustion feature. Additionally, the combustion performance of digested sewage sludge is more negative than the others.
\end{abstract}

(c) 2014 Elsevier Ltd. All rights reserved.

\section{Introduction}

Sewage sludge produced in wastewater treatment plants (WWTPs) is currently a problem because elevated amounts of sludge are generated with increasingly stringent wastewater treatment requirements (Wang et al., 2012b). European statistics indicated that the dry weight of sewage sludge production is nearly $90 \mathrm{~g}$ per capita per day (Davis, 1996), and the implementation of wastewater management regulations has caused approximately 10 million tons of additional sewage sludge generated yearly since 2005 (Werle and Wilk, 2010). About 30 million tons of sewage sludge is produced in China (Khan et al., 2013). Sewage sludge that is not properly disposed will lead to other environmental issues, such as greenhouse gas emissions (Wang et al., 2012a).

Dried sewage sludge contains a high quantity of organic matter and has a substantial calorific value. Sewage sludge is recognized as an alternative feedstock for power generation via combustion and can be used for energy crisis mitigation (Garcia et al., 2013; Werther and Ogada, 1999). This emerging practice can facilitate

\footnotetext{
* Corresponding author. Tel./fax: +86 01062849133.

E-mail address: jxliu@rcees.ac.cn (J. Liu).
}

the substantial reduction of for-disposal sewage sludge amount because detrimental substances are removed when sewage sludge is used for power generation. Thus, energy recovery through sludge combustion is no longer a possibility, but rather an obvious reality. The sludge combustion process (SCP) has been extensively studied. However, information is still lacking on the combustion performance of sewage sludge and its connection with sludge composition. Sewage sludge contains a variety of complex components, and each constituent shows specific burning features unlike single-solid fuels, such as coal (Viet et al., 2013). Previous studies on SCPs have only addressed small components of a comprehensive technical scheme (Ogada and Werther, 1996); (Francisca Gómez-Rico et al., 2005). Designing and operating an industrialscale SCP still requires reliable information on feedstock characteristics, which has been historically obtained from semi-empirical tests. This lack of data often presents a problem in the scale-up stage because the contributions of all complex constituents in real sewage sludge to SCP efficiency are not considered in experiencebased models.

Thermogravimetry (TG) and differential thermogravimetric (DTG) analyses are widely applied in the comparative evaluation of varying thermal processes in the combustion system (Su et al., 
2013). These methods can rapidly examine multiple combusting indices (e.g., maximum combustion rate, ignition temperature, and burnout temperature). In particular, TG can monitor the sample mass of substance as a function of temperature and/or time, whereas DTG is an approach performed by detecting the rate of mass loss. These two approaches have been used recently in thermal degradation of biomass samples (Eero, 1981; Jakab et al., 1997; Meszaros et al., 2007; Sebestyén et al., 2011; Shafizadeh, 1968; Varhegyi et al., 1988; Villanueva et al., 2011; Wilson et al., 2011), investigations of sewage sludge pyrolysis (Dumpelmann et al., 1991; Magdziarz and Werle, 2014), and combustion (Font et al., 2001; Magdziarz and Wilk, 2013), as well as co-combustion of sewage sludge and other substances (Otero et al., 2002; Park and Jang, 2011; Yu and Li, 2014). Operation parameters of SCPs, such as temperature and atmosphere conditions, were also evaluated using both TG and DTG approaches (Calvo et al., 2013; Manara and Zabaniotou, 2012). The dynamic connection between sludge characteristics and SCP performance using TG and DTG techniques should be explored. However, little research has been conducted from this perspective at a comprehensive scale.

We aimed to investigate the relevant effects of sewage sludge composition on SCP performance and the consequences of such effects. The most significant constituent for SCP performance was also estimated to provide a reference basis for the future design and operation of SCPs.

\section{Materials and methods}

\subsection{Brief description of sludge samples}

All sludge samples were collected from 10 municipal WWTPs in Beijing, China, in June 2012. Table 1 presents a summary of these samples. Three kinds of sewage sludge derived from WWTPs were used: primary sludge (PS) from the primary clarifiers, waste activated sludge (WAS) from secondary clarifiers, and digested sludge (DS) from anaerobic digesters. Sludge samples were freeze-dried immediately after retrieval. After lyophilization, the sludge samples were ground to 100 mesh and stored at $4{ }^{\circ} \mathrm{C}$ before further tests.

\subsection{Composition analysis of sludge samples}

A standard method was used to determine the compositions based on proximate analysis, i.e., moisture, volatiles, ash, and fixed

Table 1

Description of sludge samples.

\begin{tabular}{cllll}
\hline $\begin{array}{l}\text { Sample } \\
\text { no. }\end{array}$ & $\begin{array}{l}\text { Sample } \\
\text { source }\end{array}$ & $\begin{array}{l}\text { Capacity } \\
\left(\times 10^{4} \mathrm{~m}^{3} / \mathrm{d}\right)\end{array}$ & $\begin{array}{l}\text { Wastewater } \\
\text { source }\end{array}$ & $\begin{array}{l}\text { Treatment } \\
\text { process }^{\mathrm{b}}\end{array}$ \\
\hline 1 & WAS & 7 & $\begin{array}{l}\text { Municipal } \\
\text { Municipal }\end{array}$ & OD \\
2 & WAS & 7 & Municipal & OD \\
3 & WAS & 20 & Industrial & CASS \\
4 & WAS & 5 & Industrial & CASS \\
5 & WAS & 5 & Municipal & Inverted $\mathrm{A}^{2} / 0$ \\
6 & WAS & 20 & Municipal & $\mathrm{A}^{2} / \mathrm{O}$ \\
7 & WAS & 20 & Municipal & UCT \\
8 & WAS & 4 & Municipal & $\mathrm{A}^{2} / O$ \\
9 & PS & 60 & Municipal & $\mathrm{A}^{2} / \mathrm{O}$ \\
10 & WAS & 60 & Municipal & $\mathrm{A}^{2} / \mathrm{O}$ \\
11 & DS & 60 & Municipal & General AS \\
12 & WAS & 100 & Municipal & OD \\
13 & WAS & 8 & Municipal & CASS \\
14 & WAS & 8 &
\end{tabular}

${ }^{\text {a }}$ Sludge samples from the same sewage treatment plant are: sludge nos. 1 and 2; sludge nos. 6 and 7; sludge nos. 9, 10, and 11 .

b OD-oxidation ditch; $\mathrm{A}^{2} / \mathrm{O}$ : anaerobic-Anoxic-Oxic process; CASS-cyclic activated sludge system; UCT: a type of improved $A^{2} / 0$ process, proposed by the University of Cape Town; AS-activated sludge process. carbon (D5142-04, 2002). Proteins in various kinds of sludge originated from different sources. The PS protein was from a protein-containing substance in wastewater that settled in the primary sedimentation tank. The WAS and DS proteins were from microbial metabolism. Protein content was analyzed using a Kjeldahl instrument (UDK152). Carbohydrates and lipids were determined using a colorimetric method (Dubois et al., 1956) and an ether extraction method (Ferraz et al., 2004), respectively. The weight fractions of major elements $(\mathrm{C}, \mathrm{H}, \mathrm{O}, \mathrm{N}$, and $\mathrm{S}$ ) were analyzed by two elemental analyzers (EAI CE-440 Element Analyzer and PE-2400 II Element Analyzer), and the net calorific value (NCV) was measured using an automatic oxygen bomb calorimeter (IKAC2000).

\subsection{TGA approach of sludge samples and organic matter}

TGA on real sludge samples and representative matter for sludge organics [i.e., bovine serum albumin (BSA), casein, glucose, starch, soybean oil, and lipids extracted from the sludge] were performed using a thermogravimetric analyzer (NETZSC STA-409PC). The weight of each sample was approximately $18 \mathrm{mg}$. The furnace temperature was increased from $40^{\circ} \mathrm{C}$ to $850{ }^{\circ} \mathrm{C}$ at a rate of $10^{\circ} \mathrm{C} / \mathrm{min}$ with an air flux of $30 \mathrm{~mL} / \mathrm{min}$. The sample weight was monitored continuously as a function of temperature. Soybean oil and lipids extracted from the sludge were mixed with silicon dioxide to prevent splashing during combustion.

\subsection{Determination of combustion characteristic index (CCI)}

In this study, indicator $\mathrm{CCI}\left(\mathrm{mg}^{2} \mathrm{~min}^{-2} \mathrm{~K}^{-3}\right)$ represented the combined effect of four general combustion parameters (maximum combustion rate, average combustion rate, ignition temperature, and burnout temperature) and was used to evaluate the overall performance of SCP. Thus, CCI can be defined by the following equation according to a previous study (Wang et al., 2011):

$\mathrm{CCI}=\frac{\left(d_{w} / d_{t}\right)_{\max }\left(d_{w} / d_{t}\right)_{\text {mean }}}{T_{i}^{2} T_{h}}$

where $\left(d_{w} / d_{t}\right)_{\max }(\mathrm{mg} / \mathrm{min})$ is the maximum combustion rate, $\left(d_{w} / d_{t}\right)_{\text {mean }}(\mathrm{mg} / \mathrm{min})$ is the average combustion rate, $T_{i}(\mathrm{~K})$ is the ignition temperature, and $T_{h}(\mathrm{~K})$ is the burnout temperature. The combustion performance improved with increasing CCI (Wang et al., 2011).

\subsection{Statistics approach for correction analysis}

Statistics analysis was performed to identify the quantitative relationships of individual sludge characteristic and combustion performance, and a representative approach of univariate linear correlations was used (Ou et al., 2014; Yoshiyuki and Yutaka, 2003) with IBM SPSS Statistics 19.0 software (SPSS Inc., Chicago, IL). The Pearson's product momentum correlation coefficient was referred to as $R$ value and was used for linear estimation. The value of $R$ is in the range -1 to +1 . A value of -1 indicates a perfect negative correlation, whereas a value of +1 represents a perfect positive correlation. A value of 0 indicates the absence of correlation.

\section{Results and discussion}

\subsection{Sludge composition}

Table 2 presents detailed data on sludge composition of the samples. Volatile compounds (50-74\%) are the main components of sludge, and the amounts vary with the samples collected. The proportion of volatile compounds was lowest in sludge no. 5 $(\sim 50 \%)$ and was highest in sludge no. 8 ( $\sim 74 \%)$. Volatiles of sludge 
Table 2

Compositions analyses of sludge samples ${ }^{\mathrm{a}}$.

\begin{tabular}{|c|c|c|c|c|c|c|c|c|c|c|c|c|c|}
\hline Sample no. & $\mathrm{M}^{\mathrm{b}}$ & $\mathrm{A}^{\mathrm{b}}$ & $\mathrm{V}^{\mathrm{b}}$ & $\mathrm{FC}^{\mathrm{b}}$ & Pro $^{b}$ & $\mathrm{CHO}^{\mathrm{b}}$ & $\mathrm{L}^{\mathrm{b}}$ & $C^{b}$ & $\mathrm{H}^{\mathrm{b}}$ & $\mathrm{N}^{\mathrm{b}}$ & $S^{b}$ & $\mathrm{O}^{\mathrm{b}}$ & $\mathrm{NCV}^{\mathrm{b}}$ \\
\hline 1 & 1.80 & 27.81 & 66.27 & 4.12 & 38.55 & 9.74 & 2.23 & 36.93 & 5.71 & 6.17 & 1.26 & 25.22 & 17.11 \\
\hline 2 & 2.02 & 31.08 & 64.60 & 2.30 & 34.47 & 13.91 & 3.52 & 33.00 & 5.25 & 5.52 & 1.05 & 28.20 & 14.86 \\
\hline 3 & 1.65 & 31.65 & 64.90 & 1.80 & 37.04 & 10.42 & 1.21 & 33.58 & 5.20 & 5.93 & 1.03 & 26.54 & 15.09 \\
\hline 4 & 1.31 & 39.69 & 57.93 & 1.07 & 31.31 & 10.95 & 2.16 & 28.68 & 4.78 & 5.01 & 1.15 & 23.69 & 12.69 \\
\hline 5 & 2.36 & 46.58 & 50.00 & 1.06 & 24.13 & 9.54 & 4.97 & 23.48 & 4.06 & 3.86 & 1.39 & 29.11 & 10.51 \\
\hline 6 & 1.85 & 27.34 & 66.98 & 3.83 & 39.39 & 11.67 & 1.99 & 35.56 & 5.49 & 6.30 & 1.16 & 27.95 & 16.16 \\
\hline 7 & 1.95 & 25.69 & 70.21 & 2.16 & 40.03 & 18.25 & 1.99 & 36.10 & 5.57 & 6.40 & 1.12 & 27.37 & 16.31 \\
\hline 8 & 1.59 & 23.24 & 73.67 & 1.50 & 41.79 & 9.78 & 2.42 & 36.92 & 5.64 & 6.69 & 1.16 & 30.45 & 16.41 \\
\hline 9 & 1.72 & 39.95 & 55.37 & 2.96 & 30.31 & 6.72 & 5.14 & 30.97 & 4.72 & 4.50 & 2.75 & 25.30 & 14.23 \\
\hline 10 & 3.24 & 34.20 & 62.09 & 0.46 & 35.34 & 11.61 & 13.26 & 29.49 & 4.93 & 5.66 & 0.87 & 29.68 & 13.14 \\
\hline 11 & 1.88 & 34.93 & 59.99 & 3.20 & 30.16 & 8.98 & 14.44 & 33.16 & 4.75 & 4.83 & 3.31 & 27.33 & 12.17 \\
\hline 12 & 1.64 & 24.49 & 72.90 & 0.97 & 40.74 & 12.73 & 6.50 & 36.04 & 5.39 & 6.75 & 1.18 & 30.10 & 16.09 \\
\hline 13 & 1.41 & 27.92 & 68.82 & 1.85 & 41.57 & 10.94 & 8.85 & 36.33 & 5.29 & 6.65 & 1.24 & 27.97 & 16.40 \\
\hline 14 & 2.19 & 38.54 & 57.36 & 1.91 & 30.31 & 9.30 & 3.42 & 29.15 & 4.56 & 4.85 & 1.11 & 27.46 & 12.95 \\
\hline
\end{tabular}

a Unit: NCV MJ/Kg; others wt.\%.

b M-moisture; A-ash content; V-volatiles; FC-fixed carbon; Pro-protein; CHO-carbohydrates; L-lipid; NCV-net calorific value.

nos. 9, 10, and 11 varied even if they were derived from the same sewage treatment plant (55\%, 62\%, and 60\%, respectively). Specifically, the volatile content of PS was lower than that of DS, and the volatile content of DS was lower than that of WAS. Ash is the second largest component in sludge. The ash contents of the sludge samples amounted to $23-47 \%$. The fixed carbon and moisture contents of the sludge samples were very low (0.46-4.12\% and $1.4-3.2 \%$, respectively).

Organic matter was the main component of volatiles; and the main components, i.e., proteins, carbohydrates, and lipids, were analyzed (Table 2). Protein content was $24-44 \%$, accounting for 47.5-60.4\% of volatile compounds. The protein content of sludge no. 5 was the lowest, accounting for $24.13 \%$ of volatiles. The protein contents of all the other WAS samples were higher than in PS samples. Furthermore, the carbohydrates comprised 13.6$26.0 \%$ of all volatile compounds on average, and their contents were lower than those of proteins. The carbohydrate content of sludge no. 9 was the lowest (only 6.72\%). Compared with other contents, the lipid contents of the sludge samples were low, with an average content of only $5.15 \%$.

$\mathrm{C}, \mathrm{H}, \mathrm{O}, \mathrm{N}$, and $\mathrm{S}$ were the main elemental components of sludge, accounting for $62-81 \%$ of the total elements. Sludge also contained other elements, such as $\mathrm{Ca}, \mathrm{Si}, \mathrm{K}, \mathrm{P}, \mathrm{Fe}, \mathrm{Mn}, \mathrm{Mo}, \mathrm{B}, \mathrm{Cr}, \mathrm{Cu}, \mathrm{Zn}, \mathrm{Ni}$, and $\mathrm{Pb}$. Obviously, $\mathrm{C}$ was the most abundant element in the 14 sludge samples, and element $\mathrm{S}$ was the least abundant. The highest $\mathrm{C}$ content reached $37 \%$ (in sludge nos. 1 and 8 ), and the lowest $C$ content was $24 \%$ (in sludge no. 5 ).

The exhaust gases generated in SCPs mainly comprised oxides of carbon $\left(\mathrm{CO}_{x}\right)$, nitrogen $\left(\mathrm{NO}_{x}\right)$, and sulfur $\left(\mathrm{SO}_{x}\right)$, and $\mathrm{H}_{2} \mathrm{O}$, which is estimated to vary significantly with the sludge components (Magdziarz and Wilk, 2013). N content was highest in sludge nos. 8 and 12 among the investigated sludge samples; hence, a high $\mathrm{NO}_{x}$ emission could be expected considerably. The highest $\mathrm{CO}_{x}$ concentration was predicted during the combustion of sludge nos. 1 and 8 , which had the highest $C$ contents. The contents of $S$ in PS (sludge no. 9) and DS (sludge no. 11) were approximately 2-fold to 3-fold higher than in WAS. Sludge with high S content may produce more sulfur dioxide $\left(\mathrm{SO}_{2}\right)$ during the combustion process, and $\mathrm{SO}_{2}$ emissions will increase the difficulty and cost of subsequent processing for air pollution control.

The NCV of biomass is crucial for the conversion of biomass to energy and biofuels. Table 2 shows the variation of NCVs (10.51$17.12 \mathrm{MJ} / \mathrm{kg}$ ) of various sludge samples. Sludge NCV was affected by moisture, ash, and oxygen contents, and the drying process (Magdziarz and Werle, 2014). Sludge no. 5, which had the highest ash content (46.58\%), had the lowest NCV (10.51 MJ/kg).

\subsection{TGA of sludge}

The sludge samples were heated from $40{ }^{\circ} \mathrm{C}$ to $850 \mathrm{C}$ in the TGA process. Combustion of the samples took place with increasing temperature and with associated mass losses, which were observed in the TG and DTG curves (Fig. 1). The curves for sludge nos. 2 and 3 were similar to that of sludge no. 1, and the curve of sludge no. 6 was similar to that of sludge no. 7 .

Fig. 1 shows the TG and DTG curves of sludge samples. The shapes of the TG and DTG curves varied for different sludge samples. The lowest weight loss was observed for sludge no. 5, which had the lowest volatile content. The DTG curves revealed the weight loss rate, i.e., the combustion rate. Fig. 1 shows that the weight loss rate of sludge no. 5 , which had the lowest volatile and protein contents ( $50 \%$ and $24 \%$, respectively), was significantly lower than those of the other sludge samples. The weight loss rate of sludge no. 8 , which had the highest volatile and protein contents ( $74 \%$ and $42 \%$, respectively), was the largest. The numbers of weight loss peak in the DTG curves of sludge samples are also different. No obvious peak appeared in the range $175-300^{\circ} \mathrm{C}$ for sludge nos. 9, 11, and 14, but all other sludge samples showed obvious peaks. The different peak numbers were related to the airflow rate and composition of the sludge samples (Norton, 1993). However, the present test was conducted under the same airflow speed. Therefore, the phenomena of different peak numbers may be related to the sludge composition. If the content of a substance that combusted in the range $175-300^{\circ} \mathrm{C}$ was insufficient, a peak may not appear in such a temperature range. Table 2 shows that the carbohydrates contents of sludge nos. 9, 11, and 14 were the lowest, i.e., $6.72 \%, 8.98 \%$, and $9.30 \%$, respectively. The low carbohydrate content may explain the absence of a peak at $175-300^{\circ} \mathrm{C}$ in the DTG curve.

The TG curves of sludge samples showed continuous mass loss. This occurred in stages for all sludge samples in combustion. Sludge weight losses were divided into five stages based on temperature and according to the TG curves: $40-175^{\circ} \mathrm{C}, 175-300^{\circ} \mathrm{C}$, $300-400{ }^{\circ} \mathrm{C}, 400-600^{\circ} \mathrm{C}$, and $600-850^{\circ} \mathrm{C}$. The first stage is often attributed to water volatilization (Werther et al., 1995; Zhao et al., 2013), and the weight losses in the first stage were 5.01$9.42 \%$ here. However, the moisture contents of the samples were only $1.4-3.2 \%$ (Table 2 ). The weight losses in the first stage were much higher than the moisture contents. Hence, some very light volatile compounds also evaporate at this stage, as mentioned in a previous study (Magdziarz and Wilk, 2013). The weight loss in the second and third stages represented the combustion of volatiles. The second stage involved the combustion of biodegradable 

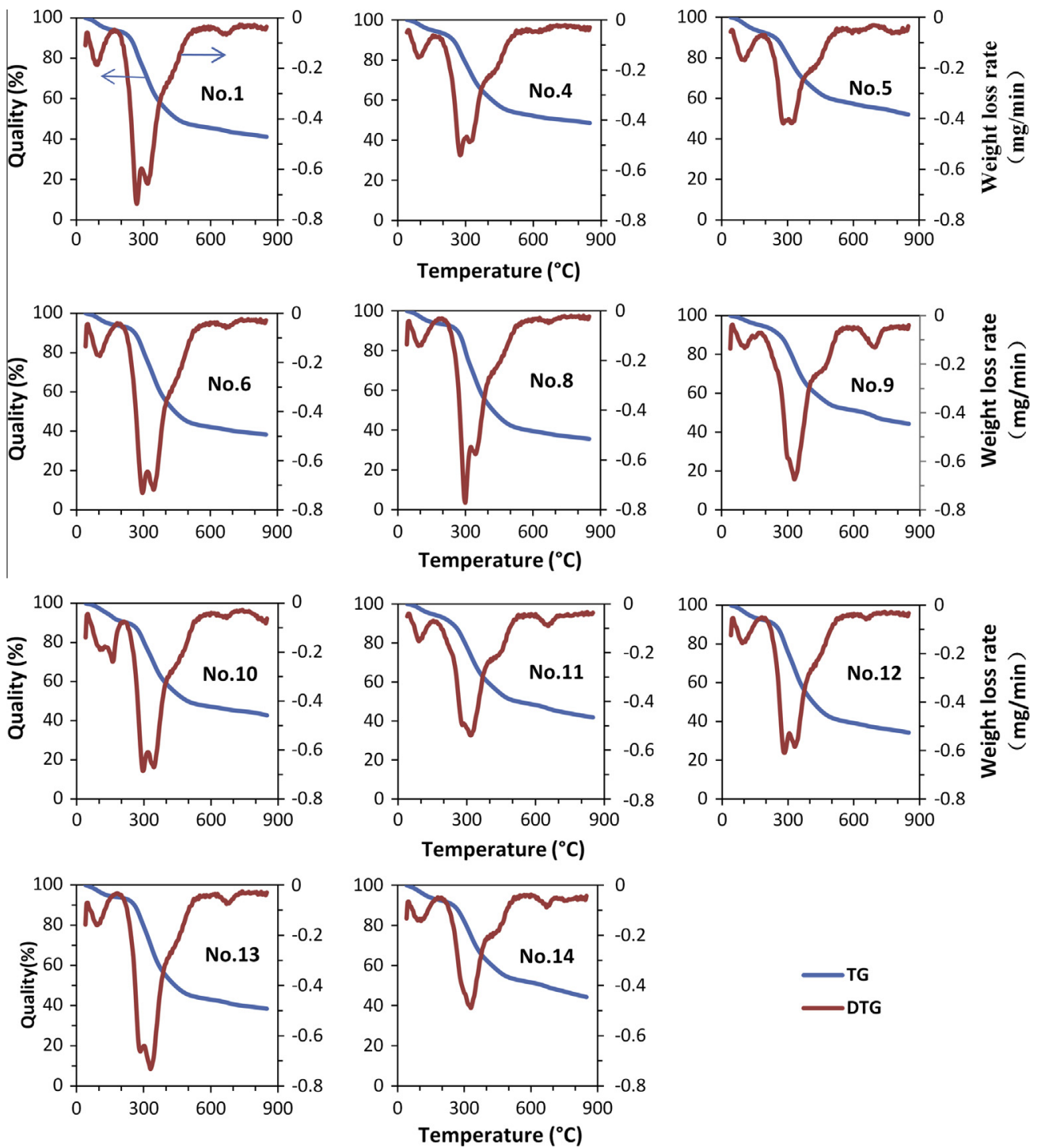

Fig. 1. TG and DTG curves of sludge samples.

small-molecule organic compounds, while the third stage represented the combustion of macromolecule organic matter (Barneto et al., 2009). The weight losses during the second and the third stages contributed approximately $77 \%$ of the total weight loss. In the fourth stage, the shoulder in the DTG curves was due to the combustion of fixed carbon. The mass loss in the fifth stage was mainly due to $\mathrm{CaCO}_{3}$ decomposition (Folgueras et al., 2013).

Table 3 shows the TGA results, including maximum combustion rate, average combustion rate, ignition temperature, burnout temperature, and CCI. Sludge no. 5 had the lowest maximum combustion rate, the lowest average combustion rate, and the highest burnout temperature. The ignition temperature of PS sample (sludge no. 9) was lower than that of WAS and DS samples (except sludge no. 14), thereby showing that PS is easy to ignite. The CCIs of sludge nos. 6,7 , and 8 were high, thereby indicating that these sludge samples have good comprehensive combustion performances. The average WAS CCI of $4.3 \times 10^{-10} \mathrm{mg}^{2} \mathrm{~min}^{-2} \mathrm{~K}^{-3}$ was higher than that of DS (sludge no. 11, $3.54 \times 10^{-10} \mathrm{mg}^{2} \mathrm{~min}^{-2} \mathrm{~K}^{-3}$ ).

\subsection{TGA of organic matter}

As mentioned above, the most important components of sludge are the proteins, carbohydrates, and lipids, which account for
Table 3

Characteristic sludge combustion parameters.

\begin{tabular}{clllll}
\hline $\begin{array}{l}\text { Sludge } \\
\text { no. }\end{array}$ & $\begin{array}{l}\left(d_{w} / d_{t}\right)_{\max } \\
(\mathrm{mg} / \mathrm{min})\end{array}$ & $\begin{array}{l}\left(d_{w} / d_{t}\right)_{\text {mean }} \\
(\mathrm{mg} / \mathrm{min})\end{array}$ & $T_{i}(\mathrm{~K})$ & $T_{h}(\mathrm{~K})$ & $\begin{array}{l}\mathrm{CCI}\left(10^{-10}\right. \\
\left.\mathrm{mg}^{2} /\left(\mathrm{min}^{2} \mathrm{~K}^{3}\right)\right)\end{array}$ \\
\hline 1 & 0.66 & 0.16 & 473.98 & 1031.48 & 4.51 \\
2 & 0.72 & 0.17 & 483.98 & 1078.98 & 4.77 \\
3 & 0.74 & 0.17 & 480.65 & 1047.32 & 5.25 \\
4 & 0.54 & 0.14 & 477.32 & 1054.82 & 3.14 \\
5 & 0.42 & 0.13 & 488.98 & 1081.48 & 2.14 \\
6 & 0.73 & 0.19 & 502.32 & 1028.98 & 5.46 \\
7 & 0.73 & 0.18 & 500.65 & 1024.83 & 5.24 \\
8 & 0.78 & 0.19 & 513.15 & 1023.98 & 5.47 \\
9 & 0.67 & 0.17 & 473.98 & 1064.82 & 4.90 \\
10 & 0.69 & 0.18 & 503.15 & 1078.98 & 4.62 \\
11 & 0.54 & 0.15 & 495.65 & 1053.15 & 3.54 \\
12 & 0.62 & 0.16 & 499.82 & 1035.65 & 3.73 \\
13 & 0.73 & 0.17 & 506.48 & 1080.65 & 4.90 \\
14 & 0.49 & 0.13 & 463.98 & 1062.32 & 2.37 \\
\hline
\end{tabular}

$\left(\left(d_{w}\right) /\left(d_{t}\right)\right)_{\max }$ is the maximum combustion rate, $\left(\left(d_{w}\right) /\left(d_{t}\right)\right)_{\text {mean }}$ is the average combustion rate, $T_{i}$ is the ignition temperature, $T_{h}$ is the burnout temperature.

$76-97 \%$ of the sludge volatile contents. Therefore, the combustion characteristics of these organic materials were analyzed in detail in the following Section. BSA protein, casein, glucose, starch, soybean 
oil, and lipid extracted from the sludge were investigated using TGA, and the relevant TG-DTG curves are shown in Fig. 2. The first stage was mainly associated with moisture vaporization, whereas in the second and third stages, the samples were subjected to organic matter combustion. The fourth and the fifth stages failed to occur because the organic materials were pure substances, except for fixed carbon and inorganic substances. Fig. 2 shows that all these organic compounds showed weight losses in the second and third stages. The weight losses in the second stage for BSA protein, casein, glucose, starch, soybean oil, and lipids extracted from sludge amounted to $0.8,0.8,2.2,2.5,2.3$, and 3.2 times of those in the third stage, respectively. Therefore, the protein contents (BSA protein and casein) in the two main weight loss stages did not obviously differ. However, the weight losses for carbohydrates (glucose and starch) and lipids (soybean oil and lipid extracted from sludge) in the second stage were greater than those in the third stage.

The weight loss rate peaks in the second stage of the DTG curves of glucose and starch were higher than those in the third stage. The maximum combustion rates of glucose in the second and third stages were 0.38 and $0.14 \mathrm{mg} / \mathrm{min}$, respectively. The maximum combustion rate of glucose in the second stage was 2.7 times that in the third stage. The peak values for starch in the second and third stages were 1.26 and $0.13 \mathrm{mg} / \mathrm{min}$, respectively. The maximum combustion rate of starch in the second stage was approximately 10 times that in the third stage. The maximum combustion rate of carbohydrates in the second stage was much higher than that in the third stage. The maximum combustion rates of glucose $\left(0.37 \mathrm{mg} \mathrm{min}^{-1}\right)$ and starch (1.25 $\mathrm{mg} \mathrm{min}^{-1}$ ) were much higher than those of other organic substances (Fig. 2). Therefore, carbohydrate content had a significant effect on the sludge combustion rate in the second stage. Low carbohydrate content resulted in low combustion rate in the second stage. A sufficiently high third peak resulted in a non-obvious second peak. In this case, no obvious peak appeared in the second stage, as observed in the DTG curves of sludge nos. 9, 11, and 14 .

The glucose ignition temperature $\left(135^{\circ} \mathrm{C}\right)$ could be determined from the TG and DTG curves of glucose (Fig. 2). This finding also confirmed that small-molecule volatiles were released during the first stage $\left(40-175^{\circ} \mathrm{C}\right)$ of sludge combustion.

\subsection{Effect of sludge components on combustion performance}

A comparison of the volatile content and the $\mathrm{CCI}$ of the sludge samples showed that the highest CCI was found in sludge no. 8 , which had the highest volatile content (74\%). The lowest CCI was found in sludge no. 5, which had the lowest volatile content (50\%). A comparison of the maximum combustion rates and the volatile content of these sludge samples showed that the $\mathrm{CCI}$ values of sludge nos. 5 and 8 were the lowest and highest, respectively. Thus, the maximum combustion rate of sludge was associated with volatile content. As studied previously (Ischia et al.,
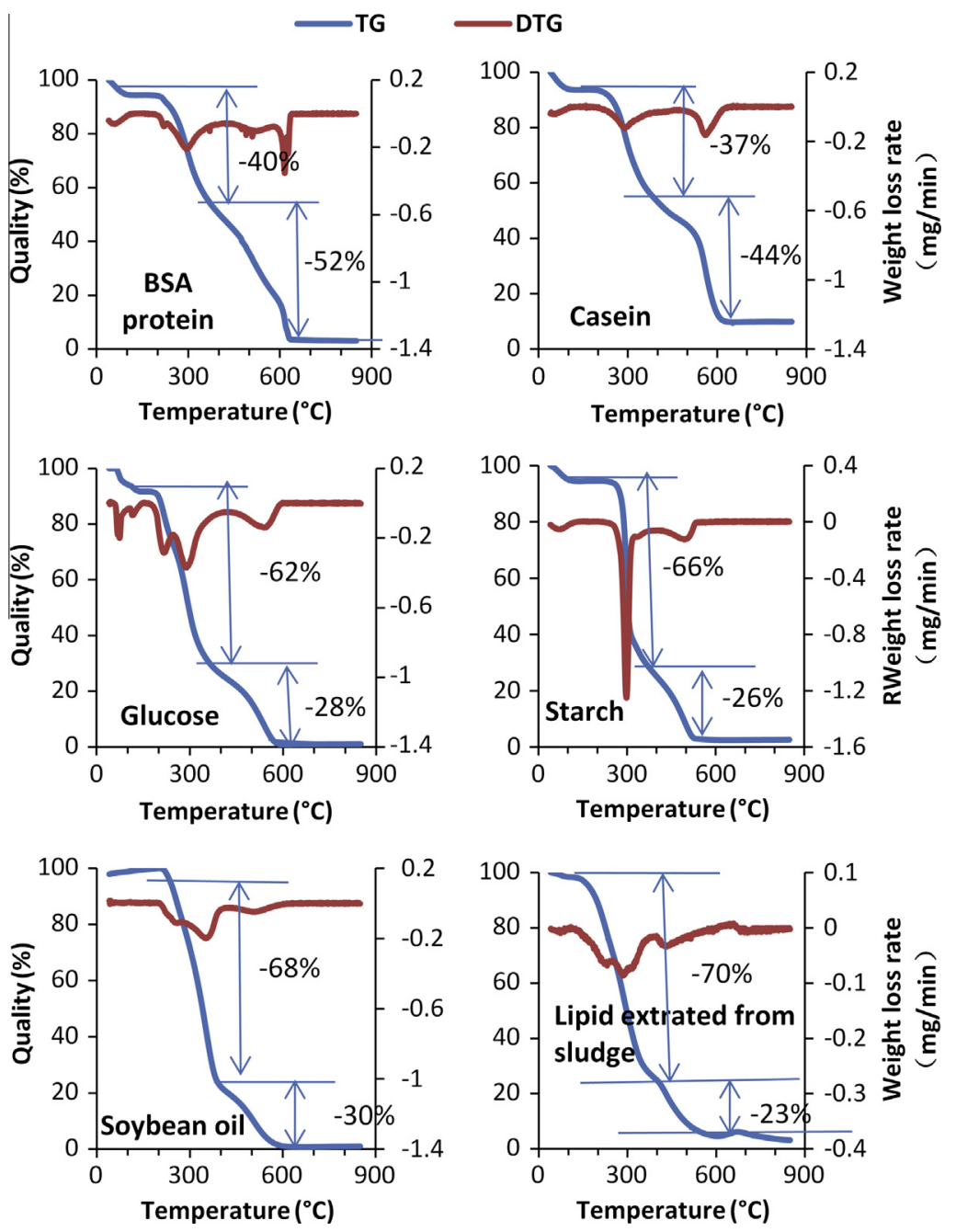

Fig. 2. TG and DTG curves of organic components. 
Table 4

Correlation coefficient of sludge compositions and combustion performance.

\begin{tabular}{|c|c|c|c|c|c|c|c|c|c|c|c|c|c|c|}
\hline & M & A & V & FC & Pro & PS & $\mathrm{L}$ & C & $\mathrm{H}$ & $\mathrm{N}$ & $S$ & 0 & $\mathrm{NCV}$ & $\mathrm{CCI}$ \\
\hline$M$ & 1 & - & - & - & - & - & - & - & - & - & - & - & - & - \\
\hline A & 0.29 & 1 & - & - & - & - & - & - & - & - & - & - & - & - \\
\hline V & -0.32 & $-0.99^{*}$ & 1 & - & - & - & - & - & - & - & - & - & - & - \\
\hline FC & -0.28 & -0.20 & 0.06 & 1 & - & - & - & - & - & - & - & - & - & - \\
\hline Pro & -0.28 & $-0.96^{*}$ & $0.97^{*}$ & 0.02 & 1 & - & - & - & - & - & - & - & - & - \\
\hline PS & 0.08 & -0.49 & 0.51 & -0.17 & 0.46 & 1 & - & - & - & - & - & - & - & - \\
\hline $\mathrm{L}$ & 0.44 & 0.15 & -0.15 & -0.18 & -0.18 & -0.19 & 1 & - & - & - & - & - & - & - \\
\hline C & -0.46 & $-0.94^{*}$ & $0.91^{* *}$ & 0.44 & $0.90^{* *}$ & 0.33 & -0.14 & 1 & - & - & - & - & - & - \\
\hline $\mathrm{H}$ & -0.34 & $-0.95^{*}$ & $0.92^{* *}$ & 0.34 & $0.94^{* *}$ & 0.46 & -0.31 & $0.94^{*}$ & 1 & - & - & - & - & - \\
\hline $\mathrm{N}$ & -0.29 & $-0.96^{* *}$ & $0.98^{* * *}$ & 0.06 & $0.99^{* *}$ & 0.49 & -0.17 & $0.88^{* *}$ & $0.92^{* * *}$ & 1 & - & - & - & - \\
\hline $\mathrm{S}$ & -0.15 & 0.31 & -0.36 & 0.42 & -0.42 & -0.50 & 0.48 & -0.07 & -0.34 & -0.49 & 1 & - & - & - \\
\hline 0 & 0.41 & -0.34 & 0.38 & -0.42 & 0.27 & 0.21 & 0.31 & 0.11 & 0.11 & 0.35 & -0.25 & 1 & - & - \\
\hline NCV & -0.42 & $-0.90^{* *}$ & $0.87^{* *}$ & 0.37 & $0.93^{* *}$ & 0.36 & -0.38 & $0.92^{* *}$ & $0.95^{* *}$ & $0.86^{* *}$ & -0.32 & 0.07 & 1 & - \\
\hline $\mathrm{CCI}$ & -0.18 & $-0.71^{* *}$ & $0.67^{* *}$ & 0.32 & $0.75^{* * *}$ & 0.30 & -0.18 & $0.73^{* *}$ & $0.78^{* * *}$ & $0.62^{*}$ & -0.13 & 0.08 & $0.77^{* *}$ & 1 \\
\hline
\end{tabular}

M moisture; A ash content; V volatiles; FC fixed carbon; Pro protein; CHO carbohydrates; L lipid; NCV net calorific value.

** Correlation is significant at the 0.01 level (2-tailed).

* Correlation is significant at the 0.05 level (2-tailed).

2007; Magdziarz and Wilk, 2013), the main components of ash generally include a variety of stable inorganic compounds, such as $\mathrm{SiO}_{2}, \mathrm{CaO}, \mathrm{MgO}, \mathrm{Fe}_{2} \mathrm{O}_{3}$, and $\mathrm{Al}_{2} \mathrm{O}_{3}$, the combustion of which will require additional heat. Hence, relatively low $\mathrm{CCI}$ scores were observed with high ash contents among the samples.

The main components of volatile compounds were proteins, which accounted for $46-60 \%$ of the total volatile components. A comparison of $\mathrm{CCI}$ and protein content showed that sludge no. 8 had the highest protein content and CCI scores, whereas sludge no. 5 had the lowest values for these parameters. Thus, protein content was connected closely with sludge combustion performance.

To determine the key factors affecting combustion performance, Pearson correlation of CCIs and sludge characteristics were analyzed subsequently. Table 4 shows the $R$ values among the CCIs and sludge characteristics. The $R$ values of $\mathrm{CCI}$ and protein were higher than those of CCI and volatiles ( 0.75 vs. 0.67 ), thereby showing that a much higher correlation was observed between CCI and protein content. Unlike proteins, carbohydrates and lipids did not show a good correlation with CCI. Additionally, correlations between combustion performance and caloric value were also estimated in a previous literature (Sebestyén et al., 2011). The elements of $\mathrm{C}, \mathrm{H}$ and $\mathrm{N}$, which are important components of protein, were also estimated to be highly linked with CCI in the present work. Overall, the volatile compounds, particularly proteins, are the important factors that affect sludge combustion performance.

\section{Conclusions}

The combustion characteristics of numerous representative sludge samples were studied in this work. Differences were found between these samples, and these samples varied substantially in terms of sludge composition. Specifically, much higher correlations were found between combustion performance and the content of proteins. Unlike proteins, carbohydrates and lipids were negatively linked with combustion performance. Nevertheless, the combustion of carbohydrates was mainly found in the second stage, and the combustion rate was marked higher than those of other organic substances. Owing to the specific features of carbohydrates, sludge nos. 9, 11, and 14, which had the lowest carbohydrates content, showed no peak in the DTG curve in the second stage. In addition, the combustion performance of DS was observed to be more negative compared with other types of sewage sludge. Thus, DS is not recommended for direct combustion in this work. Further research is needed for clarity.

\section{Acknowledgments}

This work is financially supported by the National Science Foundation of China (No. 51138009), the Major Science and Technology Program for Water Pollution Control and Treatment (2012ZX07203-001), and the State Key Joint Laboratory of Environment Simulation and Pollution Control of China (No. 14Z03ESPCR).

\section{References}

Barneto, A.G., Carmona, J.A., Martin, J.E., Blanco, J.D., 2009. Kinetic models based in biomass components for the combustion and pyrolysis of sewage sludge and its compost. J. Anal. Appl. Pyrol. 86, 108-114.

Calvo, A.I., Tarelho, L.A.C., Teixeira, E.R., Alves, C., Nunes, T., Duarte, M., Coz, E. Custodio, D., Castro, A., Artinano, B., Fraile, R., 2013. Particulate emissions from the co-combustion of forest biomass and sewage sludge in a bubbling fluidised bed reactor. Fuel Process. Technol. 114, 58-68.

D5142-04, A.-. 2002. Standard test methods for proximate analysis of the analysis sample of coal and coke by instrumental procedures. In: Materials, A.S.f.T.a. (Ed.), Annual Book of ASTM Standards, West Conshohocken, PA.

Davis, R.D., 1996. The impact of EU and UK environmental pressures on the future of sludge treatment and disposal. J. Chart. Inst. Water Environ. Manage. 10, 65-69.

Dubois, M. Gilles, K.A., Hamilton, J.K., Rebers, P.A., Smith, F., 1956. Colorimetric method for determination of sugars and related substances. Anal. Chem. 28, 350-356.

Dumpelmann, R., Richarz, W., Stammbach, M.R., 1991. Kinetic-studies of the pyrolysis of sewage-sludge by TGA and comparison with fluidized-beds. Can. J. Chem. Eng. 69, 953-963.

Eero, S., 1981. Wood chemistry-fundamentals and applications. Academic Press, New York.

Ferraz, T.P., Fiuza, M.C., Dos Santos, M.L., Pontes De Carvalho, L., Soares, N.M., 2004 Comparison of six methods for the extraction of lipids from serum in terms of effectiveness and protein preservation. J. Biochem. Biophys. Methods 58, 187193.

Folgueras, M.B., Alonso, M., Díaz, R.M., 2013. Influence of sewage sludge treatment on pyrolysis and combustion of dry sludge. Energy 55, 426-435.

Font, R., Fullana, A., Conesa, J.A., Llavador, F, 2001. Analysis of the pyrolysis and combustion of different sewage sludges by TG. J. Anal. Appl. Pyrol. 58, 927-941.

Francisca Gómez-Rico, M., Font, R., Fullana, A., Martín-Gullón, I., 2005. Thermogravimetric study of different sewage sludges and their relationship with the nitrogen content. J. Anal. Appl. Pyrol. 74, 421-428.

Garcia, G., Arauzo, J., Gonzalo, A., Sanchez, J.L., Abrego, J., 2013. Influence of feedstock composition in fluidised bed co-gasification of mixtures of lignite bituminous coal and sewage sludge. Chem. Eng. J. 222, 345-352.

Ischia, M., Perazzolli, C., Dal Maschio, R., Campostrini, R., 2007. Pyrolysis study of sewage sludge by TG-MS and TG-GC-MS coupled analyses. J. Therm. Anal. Calorim. 87, 7.

Jakab, E., Faix, O., Till, F., 1997. Thermal decomposition of milled wood lignins studied by thermogravimetry mass spectrometry. J. Anal. Appl. Pyrol. 40-1, $171-186$.

Khan, S., Wang, N., Reid, B.J., Freddo, A., Cai, C., 2013. Reduced bioaccumulation of PAHs by Lactuca satuva L. grown in contaminated soil amended with sewage sludge and sewage sludge derived biochar. Environ. Pollut. 175, 64-68.

Magdziarz, A., Werle, S., 2014. Analysis of the combustion and pyrolysis of dried sewage sludge by TGA and MS. Waste Manage. 34, 174-179.

Magdziarz, A., Wilk, M., 2013. Thermal characteristics of the combustion process of biomass and sewage sludge. J. Therm. Anal. Calorim. 114, 519-529. 
Manara, P., Zabaniotou, A., 2012. Towards sewage sludge based biofuels via thermochemical conversion - a review. Renew. Sust. Energy Rev. 16, 2566 2582.

Meszaros, E., Jakab, E., Varhegyi, G., Tovari, P., 2007. Thermogravimetry/mass spectrometry analysis of energy crops. J. Therm. Anal. Calorim. 88, 477-482.

Norton, G.A., 1993. A review of the derivative thermogravimetric technique (Burning Profile) for fuel combustion studies. Thermochim. Acta 214, 171-182.

Ogada, T., Werther, J., 1996. Combustion characteristics of wet sludge in a fluidized bed - release and combustion of the volatiles. Fuel 75, 617-626.

Otero, M., Diez, C., Calvo, L.F., Garcia, A.I., Moran, A., 2002. Analysis of the cocombustion of sewage sludge and coal by TG-MS. Biomass Bioenergy 22, 319 329.

Ou, H.S., Wei, C.H., Mo, C.H., Wu, H.Z., Ren, Y., Feng, C.H., 2014. Novel insights into anoxic/aerobic(1)/aerobic(2) biological fluidized-bed system for coke wastewater treatment by fluorescence excitation-emission matrix spectra coupled with parallel factor analysis. Chemosphere 113, 158-164.

Park, S.W., Jang, C.H., 2011. Characteristics of carbonized sludge for co-combustion in pulverized coal power plants. Waste Manage. 31, 523-529.

Sebestyén, Z. Lezsovits, F. Jakab, E., Várhegyi, G., 2011. Correlation between heating values and thermogravimetric data of sewage sludge, herbaceous crops and wood samples. J. Therm. Anal. Calorim. 110, 1501-1509.

Shafizadeh, F., 1968. Pyrolysis and combustion of cellulosic materials. Adv. Carbohydr. Chem. 23, 419-474.

Su, W., Ma, H., Wang, Q., Li, J., Ma, J., 2013. Thermal behavior and gaseous emission analysis during co-combustion of ethanol fermentation residue from food waste and coal using TG-FTIR. J. Anal. Appl. Pyrol. 99, 79-84.

Varhegyi, G., Antal, M.J., Szekely, T., Till, F., Jakab, E., 1988. Simultaneous thermogravimetric mass-spectrometric studies of the thermal-decomposition of bio-polymers. 1. Avicel cellulose in the presence and absence of catalysts. Energy Fuel 2, 267-272.

Viet, N.T., Dieu, T.T.M., Loan, N.T.P., 2013. Current status of sludge collection, transportation and treatment in Ho Chi Minh city. J. Environ. Protect. 04, 13291335.
Villanueva, M., Proupin, J., Rodriguez-Anon, J.A., Fraga-Grueiro, L., Salgado, J., Barros, N., 2011. Energetic characterization of forest biomass by calorimetry and thermal analysis. J. Therm. Anal. Calorim. 104, 61-67.

Wang, L., Guo, Y., Zhu, Y., Qu, Y., Li, Y., Rong, C., Wang, Z., Liu, Y., 2011. Investigation on catalyzed combustion of wheat straw by thermal analysis. Thermochim. Acta $512,254-257$.

Wang, X., Liu, J.X., Ren, N.Q., Duan, Z.S., 2012a. Environmental profile of typical anaerobic/anoxic/oxic wastewater treatment systems meeting increasingly stringent treatment standards from a life cycle perspective. Bioresour. Technol. 126, 31-40.

Wang, X., Liu, J.X., Ren, N.Q., Yu, H.Q., Lee, D.J., Guo, X.S., 2012b. Assessment of multiple sustainability demands for wastewater treatment alternatives: a refined evaluation scheme and case study. Environ. Sci. Technol. 46, 5542-5549.

Werle, S., Wilk, R.K., 2010. A review of methods for the thermal utilization of sewage sludge: the Polish perspective. Renewable Energy 35, 1914-1919.

Werther, J., Ogada, T., 1999. Sewage sludge combustion. Prog. Energy Combust. Sci. 25, 55-116.

Werther, J., Ogada, T., Borodulya, V.A., Dikalenko, V.I., 1995. Devolatilisation and combustion kinetic parameters of wet sewage sludge in a bubbling fluidised bed furnace. In: Proc. Inst. Of Energy's 2nd International Conference on Combustion and Emission Control., London, UK, pp. 149-158.

Wilson, L., Yang, W.H., Blasiak, W., John, G.R., Mhilu, C.F., 2011. Thermal characterization of tropical biomass feedstocks. Energy Convers. Manage 52, 191-198.

Yoshiyuki, S., Yutaka, K., 2003. Pyrolysis of plant, animal and human waste: physical and chemical characterization of the pyrolytic products. Bioresour. Technol. 90, $241-247$.

Yu, L.Y., Li, P.S., 2014. Thermogravimetric analysis of coal and sludge co-combustion with microwave radiation dehydration. J. Energy Inst. 87, 220-226.

Zhao, P., Ge, S., Yoshikawa, K., 2013. An orthogonal experimental study on solid fuel production from sewage sludge by employing steam explosion. Appl. Energy $112,1213-1221$ 